\title{
Sensitivity of crabs Callinectes sapidus and C. similis and the gastropod Stramonita haemastoma to hypoxia and anoxia
}

\author{
Tapash Das, William B. Stickle \\ Department of Zoology and Physiology, Louisiana State University, Baton Rouge, Louisiana 70803, USA
}

\begin{abstract}
Tolerances of the juvenile blue crab Callinectes sapidus Rathbun, lesser blue crab Callinectes similis Williams and the adult southern oyster drill Stramonita haemastoma Linnaeus to long-term (28 d) hypoxia and short-term (10 d) changes from normoxia to hypoxia and back to normoxia were monitored at $24^{\circ} \mathrm{C}$ and $30 \%$ S. C. sapidus was very sensitive to hypoxia with a $28 \mathrm{~d} \mathrm{LC}_{50}$ of 106 Torr $\mathrm{O}_{2}$. All C. sapidus in 25 and 0 Torr $\mathrm{O}_{2}$ died within $6 \mathrm{~d}$ of exposure. $C$. similis exhibited lesser sensitivity to hypoxia with a $28 \mathrm{~d} \mathrm{LC}_{50}$ of 43 Torr $\mathrm{O}_{2}$. All crabs exposed to anoxic water died within $3 d$ of exposure. S. haemastoma exhibited a $28 \mathrm{~d} \mathrm{LC}_{50}$ of 11.5 Torr $\mathrm{O}_{2}$. Under anoxia, initial death occurred in $S$. haemastoma after Day 11 and complete mortality occurred by Day 22. No significant difference occurred in the feeding rates of blue crabs exposed to normoxia, 119 and 73 Torr $\mathrm{O}_{2}$, but these rates were significantly higher than that in blue crabs exposed to 50 Torr $\mathrm{O}_{2}$. Feeding rates in the lesser blue crab exposed to 50 and 25 Torr $\mathrm{O}_{2}$ were significantly lower than in crabs exposed to 119 Torr $\mathrm{O}_{2}$ and normoxia. Growth and molting rates in both species of crabs were significantly higher in the normoxic exposure than in those exposed to hypoxia and anoxia. Significant differences were noticed in the feeding rate of $S$. haemastoma exposed to hypoxia from those exposed to normoxia. Feeding rate in $S$. haemastoma declined linearly with declining $\mathrm{O}_{2}$ concentration. Mean oxygen consumption rates of C. sapidus exposed to 25 and 50 Torr $\mathrm{O}_{2}$ were lower than the normoxic consumption but this rate was higher in the crabs exposed to 115 Torr $\mathrm{O}_{2}$. Mean oxygen consumption rate of $C$. similis exposed at all hypoxic levels was higher than of those exposed to normoxia, indicating overcompensation. The transfer experiment was performed only on $C$. sapidus. The feeding rate of crabs exposed to different hypoxic levels was not significantly different from those exposed to normoxia but the feeding rate increased sharply upon transfer of the juvenile blue crabs to normoxic water after $10 \mathrm{~d}$ hypoxic exposure and may have been due to partial starvation during hypoxic exposure. Number of molts after transfer to normoxia was higher in all the crabs exposed to hypoxia compared to those exposed to normoxia. Sensitivity to hypoxia can be ranked as C. sapidus $>C$. similis $>S$. haemastoma.
\end{abstract}

\section{INTRODUCTION}

Seasonal depletion of dissolved oxygen in subpycnocline waters is often observed in estuaries and nearshore waters of continental shelves (Sanford et al. 1990). Occurrence of hypoxic water masses have been reported by a number of researchers during the last decade in the U.S.: the Chesapeake Bay, New York harbor, New England estuaries and on the Louisiana continental shelf (Bedinger et al. 1981, Turner \& Allen 1982, Boesch 1983, Officer et al. 1984, Renaud 1985, 1986a, Rabalais et al. 1986a, b, Parker \& O'Reilly 1991, Portnoy 1991). Mass mortalities or massive shoreward migration of demersal fishes and crustaceans to shallow water have been reported when the dissolved oxygen level in the water was very low (Loesch 1960, May 1973, Garlo et al. 1979, Pavela et al. 1983, Pihl et al. 1991). The occurrence of hypoxic water masses off the Louisiana coast is almost an annual phenomenon and may persist for weeks (Bedinger et al. 1981, Turner \& Allen 1982, Boesch 1983, Renaud 1985, 1986a, Rabalais et al. 1986a, b). This creates a threat to marine fauna, including the blue crab Callinectes sapidus and the lesser blue crab Callinectes similis.

The blue crab Callinectes sapidus Rathbun occurs in lower reaches of rivers, estuaries, and coastal waters 
along the Atlantic seaboard and Gulf of Mexico coast of the USA (Churchill 1919, Gunter 1938, Odum 1953, Cameron 1978). Juveniles and adults occupy habitats ranging from freshwater to hypersaline waters of as high as $117 \% \mathrm{~S}$ (Williams 1984) although larvae are relatively stenohaline (Costlow \& Bookhout 1959). Salinity, water temperature, food availability, predation, substratum, available habitats and pollutants affect growth and survival of blue crabs (Gulf Coast Research Laboratory 1986, Georgia Cooperative Fishery and Wildlife Research Unit 1989). Tolerances may vary with life stages and hypoxia may also be stressful to these species. Blue crabs do not conform to specific trophic levels and are characterized as opportunistic benthic omnivores. Their high abundance, diverse feeding habits and importance as prey species for a variety of organisms make them an integral part of the coastal ecosystem.

Callinectes similis Williams is an offshore congener of the C. sapidus and occurs in the oceanic littoral zone in salinities above $15 \%$ and at a depth of almost $100 \mathrm{~m}$ (Williams 1984). The distributional patterns and niche characteristics of these 2 species overlap quite frequently and in some cases the crabs compete for food and other resources (Engel 1977). They primarily utilize the same prey groups (Hsueh et al. 1991). This high overlap in the diet of these 2 crab species suggests a competition for common resources.

The southern oyster drill Stramonita (=Thais) haemastoma Linnaeus is an important predator on oyster reefs and other hard substrates in the northern Gulf of Mexico. It is responsible for losses of up to half the yearly oyster crop in Louisiana (Cake 1983). S. haemastoma is exposed to diurnal fluxes of dissolved oxygen, ranging from 25 to $120 \%$ of saturation over a $24 \mathrm{~h}$ period, and is very tolerant of hypoxia (Kapper \& Stickle 1987, Stickle et al. 1989).

The specific objectives of this study are to: (1) compare the hypoxia tolerance of the juvenile Callinectes sapidus, and $C$. similis and adult Stramonita haemastorna; (2) quantify the effects of long-term exposure (28 d) to hypoxia on the feeding rate, growth, molting, and respiration of the juvenile $C$. sapıdus and $C$. similis and feeding rates of adult $S$. haemastoma; and (3) determine the effects of abrupt changes from different levels of hypoxia to normoxia on the survival, feeding rate, growth and molting of $C$. sapidus.

\section{MATERIALS AND METHODS}

Collection and maintenance. Callinectes sapidus were collected nearshore Ocean Springs, Mississippi, USA $\left(30^{\circ} 24.4^{\prime} \mathrm{N}, 88^{\circ} 49.9^{\prime} \mathrm{W}\right)$; C. similis were collected nearshore Port Fourchon, Louisiana, USA $\left(29^{\circ} 6.7^{\prime} \mathrm{N}\right.$, $\left.90^{\circ} 11.4^{\prime} \mathrm{W}\right)$; and Stramonita haemastoma were collected from bulkheads and jetties onshore Caminada Pass, Louisiana $\left(29^{\circ} 12.6^{\prime} \mathrm{N}, 90^{\circ} 3.0^{\prime} \mathrm{W}\right)$. All specimens were collected between August and September 1991, when the water temperatures at Ocean Springs, Port Fourchon, and Caminada Pass were 28,30 and $30^{\circ} \mathrm{C}$ and the salinities were 22,29 and $30 \%$ respectively. The specimens were brought back to the laboratory and placed into artificial seawater made from Instant Ocean, at $24^{\circ} \mathrm{C}$ and salinities matching field conditions. All specimens were kept under constant illumination. After a few days all specimens were acclimated in a step-wise fashion to the experimental salinity $(30 \%$ ). All 3 species were held for $2 \mathrm{wk}$ at the final temperature-salinity combination before being used in experiments. Blue crabs and lesser blue crabs were individually isolated as described below and were fed frozen abdominal portions of the grass shrimp Palae. monetes pugio and the oyster drills were fed live mussels Ischadium recurvum.

Hypoxia exposure system. The hypoxia exposure system consisted of 3 sets of 12 flow-through aquaria. Two aquaria were assigned for each experimental oxygen tension for each species. Each experimental aquarium (38 l) consisted of an undergravel filter overlaid with oyster chips. Water was pumped from a large filtration unit into each aquarium by a peristaltic pump at a rate sufficient to ensure the water was completely exchanged several times each day. The filtration units were large (76 1) partitioned plywood boxes lined with non-toxic Fiberglas resin. A separate filtration unit was used for each species.

Target oxygen tensions of $119,73,50,25$ and 0 Torr $(77,47,32,16$ and $0 \%$ of air saturation and $5.57,3.39$, $2.31,1.16$ and 0 ppm dissolved oxygen) were created and maintained by mixing bottled nitrogen and oxygen with Matheson gas mixers (model 7402T) along with $0.03 \%$ carbon dioxide to maintain the $\mathrm{pH}$ at approximately 7.8. Each gas mixer was connected to an outlet manifold and the air mixture was passed through the undergravel filter in each aquarium. One gas mixer was used for each oxygen level and for each species. Ambient air was used to drive the undergravel filters of the normoxic tanks (155 Torr). $\mathrm{PO}_{2}$ was always maintained within $10 \%$ of the target value in the 2 higher levels, and within $5 \%$ of the target value for the 50 and 25 Torr $\mathrm{O}_{2}$ tanks. The 0 Torr tanks were maintained within $5 \%$ of the target value for the first $6 \mathrm{~d}$ and then within $1 \%$ for the remaining $22 \mathrm{~d}$. A plexiglas lid was used to cover each aquarium and then covered with a clear plastic wrapping to minimize air exchange. The water level was maintained in each aquarium by a constant-level siphon which drained water from the aquaria into one of the filter boxes at a rate equivalent to the inflow rate. Experimental condi- 
tions (temperature, salinity, $\mathrm{PO}_{2}, \mathrm{pH}$, ammonia) were checked daily. Ammonium concentration never exceeded $25 \mu \mathrm{M}$.

Two aquaria were used at each $\mathrm{PO}_{2}$ for each species. with 16 ( 2 groups of 8 blue crabs and lesser blue crabs) and 12 ( 2 groups of 6 oyster drills) individuals used at each $\mathrm{PO}_{2}$. Within each aquarium, each crab was kept in a chamber (made from 2 pairs of PVC tubing of $21 \mathrm{~cm}$ diameter and $28 \mathrm{~cm}$ length with nylon meshed screens on both ends) to prevent cannibalism. Specimens were chosen carefully for each $\mathrm{PO}_{2}$ to minimize the weight and size differences within and among the treatments.

Hypoxia bioassay. For the $28 \mathrm{~d}$ constant hypoxic exposure experiment individuals of all 3 species were transferred directly from normoxic water (155 Torr $\mathrm{O}_{2}$ ) to different hypoxic levels $\left(119,73,50,25\right.$ and 0 Torr $\left.\mathrm{O}_{2}\right)$ and were maintained throughout the experiment. In the transfer experiment the blue crabs were exposed to 3 levels of constant hypoxia $\left(73,50\right.$ and 25 Torr $\mathrm{O}_{2}$ ) for $10 \mathrm{~d}$ and then transferred directly to normoxic water (155 Torr $\mathrm{O}_{2}$ ) and maintained for another $10 \mathrm{~d}$. This experiment was performed to investigate the amount of physiological stress involved when the oxygen concentration in water drops suddenly and returns to normal after staying at that level for several days.

Survival at each $\mathrm{PO}_{2}$ was determined daily for all 3 species throughout the experimental period. A crab was considered dead when it did not show any sign of movement after stimulation and by a color change to straw color once it was dead for more than a few hours. A snail was considered dead when both the siphon and the foot failed to respond to tactile stimulation. $\mathrm{LC}_{50}$ values were calculated for each day using the Spearman-Karber technique (Hamilton et al. 1977).

Determination of food consumption, molting, and growth rate. Both crab species were fed weighed abdominal portions of frozen grass shrimp Palaemonetes pugio ad libitum so some tissue remained at the end of the day. Uneaten portions of the food were removed, weighed and replaced with a new ration daily. Oyster drills were fed live mussels Ischadium recurvum ad libitum. The amount of dry tissue consumed daily by the drills was calculated from a dry tissue weight to length regression equation of the mussels (least squares method). Crabs and drills that died during the hypoxic exposure were excluded from the feeding rate analysis the week they died.

Growth rate was measured for the crabs only since growth of oyster drills include an increase in body tissue weight and incorporation of $\mathrm{CaCO}_{3}$ in the shell making it impossible to measure the increase in soft tissue weight. Each time a crab molted it was reweighed and the difference between the initial and final weight was converted into percent increase in weight.
Measurement of scope for growth. Scope for growth for both blue crabs and oyster drills was calculated (Table 2). Stickle et al. (1989) provided an estimate of heat dissipation in the blue crabs and the oyster drills when exposed to hypoxia and anoxia. Assuming a linear decline in the heat dissipation rate from normoxia to anoxia, a measure of respiratory energy loss can be estimated. The caloric concentration of grass shrimp Palaemonetes pugio abdominal tissue was taken from Guerin \& Stickle (1992). Scope for growth was determined using the balanced energy equation of Winberg (1960):

$$
P=(C-F)-(R+U)=A b-(R+U)
$$

where $P=$ scope for growth; $A b=$ energy absorbed from food consumed $=[C$ (energy absorbed from food) - F (energy lost as feces)]; $R=$ energy lost as respiration; $U=$ energy lost as excretion, not estimated in this study but typically only 4.5 to $11.9 \%$ of energy losses at $25^{\circ} \mathrm{C}$ and $35 \% \mathrm{~S}$ (Guerin \& Stickle 1992). Scope for growth for $C$. similis could not be calculated because heat dissipation rates under various hypoxic levels were not available.

Starvation experiment. Sixteen blue crabs were maintained under normoxia for $5 \mathrm{~d}$ and monitored for daily feeding rate, then starved for $10 \mathrm{~d}$ and monitored for daily food consumption for another $10 \mathrm{~d}$ to determine if starvation for a period of time results in an enhanced feeding rate after food is again made available.

Measurement of oxygen consumption. Oxygen consumption rates at constant $\mathrm{PO}_{2} \mathrm{~s}$ were measured using the flow-through system described by Stickle et al. (1985). Incurrent water was bubbled with a gas mixture of appropriate $\mathrm{PO}_{2}$ from a gas mixer identical to those used in the hypoxia exposure system. Water was pumped via a submersible pump from the appropriate dosing compartment through a manifold, with excess water returned to a separate reservoir via a return tube. Ten side ports from the manifold were connected to separate flow-through respiration chambers $(250 \mathrm{ml}$ ) so that a blank (control) chamber was placed at each end. Water of appropriate oxygen tension was pumped from the reservoir into the distribution manifold at a

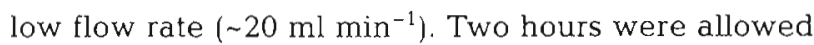
between loading crabs and the initiation of the respiration determinations to allow for crab adaptation to the chambers. Oxygen consumption in each chamber was calculated according to the following equation:

$\mu \mathrm{l} \mathrm{O}_{2} \mathrm{~h}^{-1}=\%$ oxygen used by the crab $\times$ flow rate $\left(\mathrm{l} \mathrm{h}^{-1}\right) \times 1000 \times$ oxygen content in water at that partial pressure.

Percentage oxygen used by each crab was calculated from the difference between the mean oxygen partial pressure of the water flowing out of the control 
chambers and the water flowing out of the experimental chamber and dividing that by the experimental oxygen tension. Oxygen content in the water at a particular experimental oxygen tension and salinitytemperature combination was calculated using the following equation:

\section{$A \times($ experimental oxygen tension in Torr $/ 155)$}

where $A=$ oxygen content in the normoxic water at a particular salinity-temperature combination. Water samples from the chambers were drawn anaerobically and were injected into a StrathKelvin oxygen meter (model 781) connected to a flow-through water jacketed oxygen electrode.

Statistical analysis. All rate functions were determined by either 1-way or 2-way analysis of variance (ANOVA). Differences among treatment means were determined by Tukey's range test or by Student's $t$-test. Repeated measure analysis was performed to determine differences in mean weekly food consumption between different levels and within each level of all 3 species (SAS Institute 1989). To remove effects of body weight on the measured rate functions, all rate functions were standardized to a $1 \mathrm{~g}$ unit body weight. Oxygen consumption in the 2 crab species was measured per unit ash-free dry weight (AFDW). Different regressions were used to convert wet weight to AFDW. Respiration rates were measured by a 3-way factorial analysis. Since oxygen consumption rate of different species rarely assumes either of the 2 ideal shapes (oxyconformity or oxyregulation) that describe perfect conformity or regulation (Mangum \& van Winkle 1973), mean oxygen consumption at different days and within each level and species was compared by polynomial contrasts.

\section{RESULTS \\ Response to constant hypoxic exposure \\ Callinectes sapidus}

Callinectes sapidus was very sensitive to hypoxia (Fig. 1), with a $28 \mathrm{~d} \mathrm{LC}_{50}$ of 106 Torr $\mathrm{O}_{2}$. All C. sapidus exposed to anoxia and 25 Torr $\mathrm{O}_{2}$ died within $6 \mathrm{~d}$ of exposure; $100 \%$ mortality did not occur at any other hypoxic level.

Feeding rates in Callinectes sapidus exposed to normoxia, 119 and 73 Torr $\mathrm{O}_{2}$ were not significantly different from each other (Tukey's range test) but were significantly different from the rates of crabs exposed to 50 Torr $\mathrm{O}_{2}$ (Fig. 2a). Crabs exposed to 25 and 0 Torr $\mathrm{O}_{2}$ were not included in the feeding rate analysis since $100 \%$ mortality occurred in those 2 levels within the first $6 \mathrm{~d}$ of exposure.

A significant linear decline in the feeding rate with increasing hypoxia was noticed when the feeding rate was measured on a per crab basis (Fig. 2b). The crabs exposed to normoxia grew faster than those exposed to different hypoxic levels, and their overall feeding rate was higher though the rate per unit body weight remained unchanged (Fig. 2a). Repeated measure analysis of the weekly feeding rate did not show any significant trend in the feeding rate (Fig. 3a).

Growth was measured in the blue crabs as percent increase in wet weight with respect to the initial weight of the crab. Significant differences in the growth of the crabs exposed to normoxia and those exposed to hypoxia were observed (Table 1). Only 1 crab molted at 25 Torr $\mathrm{O}_{2}$. Molting rate of the crabs

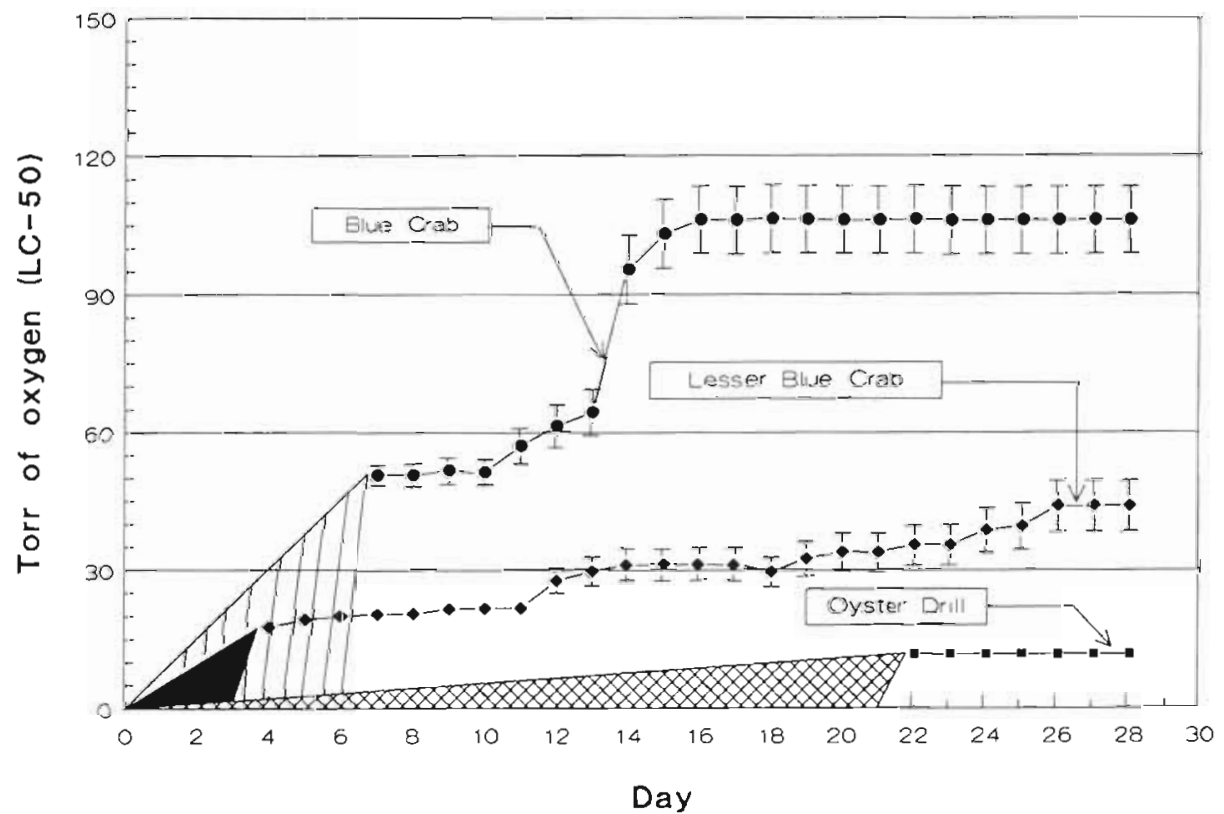

Fig. 1. $\mathrm{LC}_{50}$ of the blue crab Callinectes sapidus, the lesser blue crab C. similis, and the oyster drill Stramonita haemastoma, as a furction of hypoxia and anoxia at $30 \% \mathrm{~S}$ and $24^{\circ} \mathrm{C}$. The shaded portions indicate the period during which mortality rate was too low for $\mathrm{LC}_{50}$ calculation 

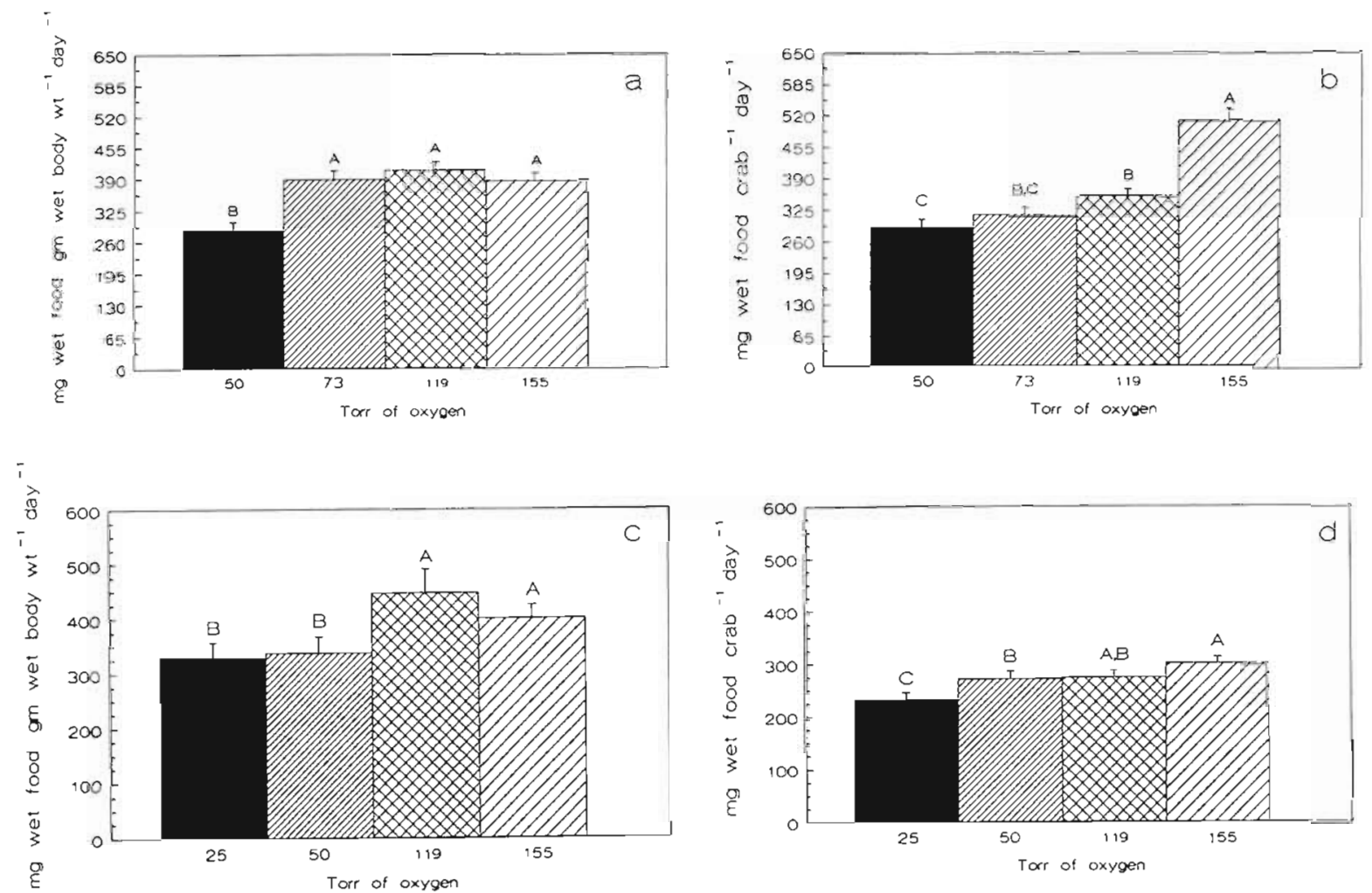

Fig. 2. Callinectes sapidus and C. similis. Average feeding rate $( \pm \mathrm{SE}$ ) of crabs exposed to various levels of hypoxia for $28 \mathrm{~d}$. Means with the same letter are not significantly different from each other (Tukey's range test). (a) Feeding rate of $C$. sapidus expressed per unit body weight. (b) Mean feeding rate per crab in $C$. sapidus. (c) Feeding rate of $C$. similis expressed per unit body weight. (d) Mean feeding rate per crab in C. similis
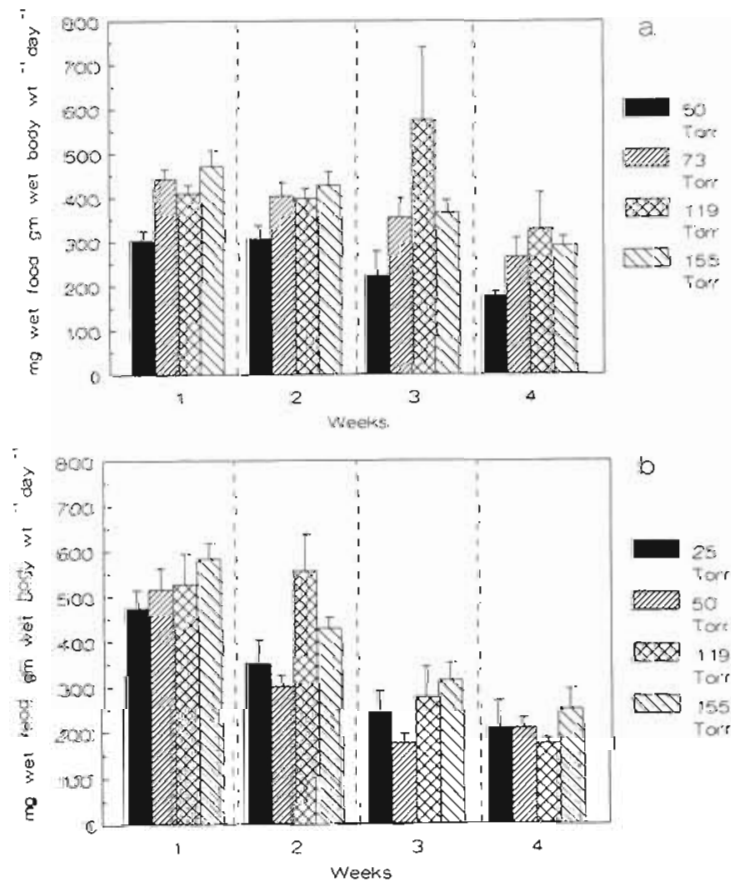

Fig. 3. Mean weekly feeding rate ( $\pm \mathrm{SE}$ ) of (a) Callinectes sapidus and (b) C. similis exposed to various levels of hypoxia for $28 \mathrm{~d}$ at $30 \% \mathrm{~S}$ and $24^{\circ} \mathrm{C}$ exposed to normoxia was faster than in the crabs exposed to different hypoxic levels (Fig. 4a). Conversely, intermolt period was shorter in the crabs exposed to normoxia than the crabs exposed to different hypoxic levels (Table 1 ).

\section{Callinectes similis}

Callinectes similis exhibited less sensitivity to hypoxia than $C$. sapidus with a $28 \mathrm{~d} \mathrm{LC}_{50}$ of 43 Torr $\mathrm{O}_{2}$ (Fig. 1). All the crabs exposed to anoxic water died within $3 \mathrm{~d}$ of exposure. $100 \%$ mortality did not occur at any other hypoxic levels.

Feeding rates of Callinectes similis exposed to normoxia (155 Torr) and 119 Torr $\mathrm{O}_{2}$ were not significantly different from each other (Tukey's range test) with a mean feeding rate of 401 and $447 \mathrm{mg}$ wet food $\mathrm{g}^{-1}$ wet body wt $\mathrm{d}^{-1}$ respectively but were significantly different from crabs exposed to 50 and 25 Torr $\mathrm{O}_{2}$ (Fig. 2c) with a mean feeding rate of 338 and $330 \mathrm{mg}$ wet food $\mathrm{g}^{-1}$ wet body wt $\mathrm{d}^{-1}$ respectively. Crabs exposed to anoxia were not included in the feeding rate analysis because of $100 \%$ mortality at that level within $3 \mathrm{~d}$. 

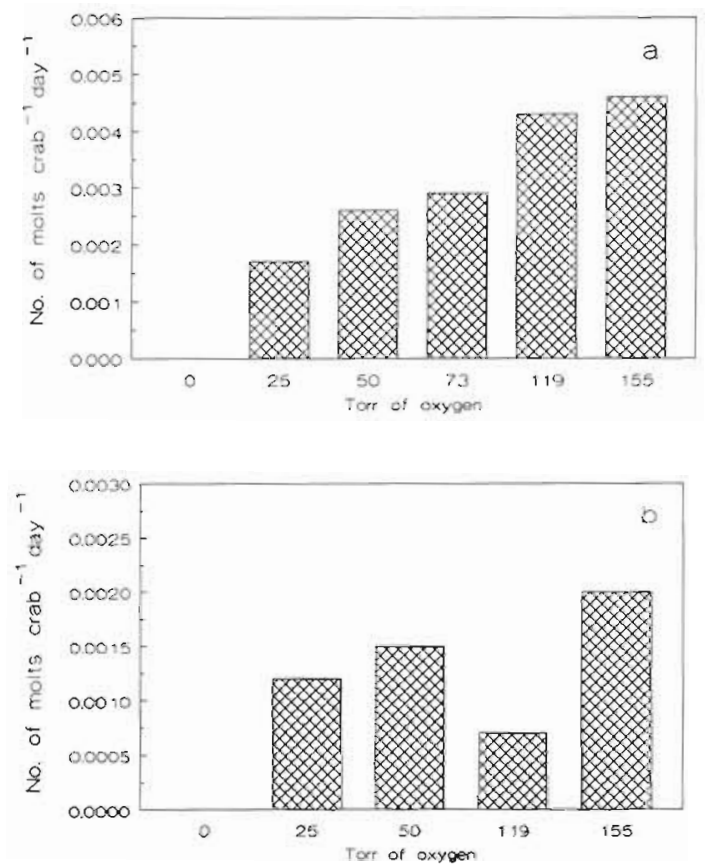

Fig. 4. Molting rate of (a) Callinectes sapidus and (b) C. similis exposed to various levels of hypoxia for $28 \mathrm{~d}$

A significant linear decline in the feeding rate with increasing hypoxia was noticed when the feeding rate was measured on a per crab basis (Fig. 2d). The crabs exposed to normoxia grew faster than those exposed to different hypoxic levels, and their overall feeding rate was higher though the rate per unit body weight was the same for 155 and 119 Torr $\mathrm{O}_{2}$ (Fig. 2C). Repeated measure analysis of the weekly feeding rate showed a significant linear decline over time (Fig. 3b).

Significant differences occurred in the growth rate of Callinectes similis exposed to normoxia (155 Torr) and those exposed to different levels of hypoxia (Table 1). Molting rate in the crabs decreased linearly with the severity of hypoxia with the only exception of 119 Torr
(Fig. 4b). The intermolt period in the crabs exposed to normoxia was shorter than that of crabs exposed to hypoxia (Table 1)

\section{Stramonita haemastoma}

Stramonita haemastoma was very resistant to hypoxia with a $28 \mathrm{~d} \mathrm{LC}_{50}$ of 11.5 Torr $\mathrm{O}_{2}$ (Fig. 1); $100 \%$ mortality occurred only under total anoxia. The first death occurred after Day 11, and all the oyster drills exposed to anoxia were dead by Day 22.

Feeding rates in all oyster drills exposed to hypoxic water were significantly different from those exposed to normoxia. Feeding rates of Stramonita haemastoma exposed to 119 and 73 Torr $\mathrm{O}_{2}$ were not significantly different from each other (Tukey's range test) but were significantly different from the drills exposed to 50 and 25 Torr $\mathrm{O}_{2}$ (Fig. 5a). The lowest feeding rate was recorded in the oyster drills exposed to anoxia. Repeated measure analysis of feeding rate by week showed a strong interaction with time within each level ( $p<0.01$; Fig. 5b).

Scope for growth in the blue crabs exposed to the 2 higher levels of hypoxia was not much different from the normoxic scope for growth, but it declined linearly in the oyster drills with the severity of hypoxia from $92 \%$ in 119 Torr $\mathrm{O}_{2}$ to $64 \%$ in 25 Torr $\mathrm{O}_{2}$ (Table 2).

\section{Response to direct transfer from constant hypoxic exposure to normoxia}

Feeding rates in the crabs exposed to various levels of hypoxia were not significantly different from those exposed to normoxia during the pre-transfer period Feeding rate of blue crabs transferred directly from various hypoxic levels to normoxia increased signifi-

Table 1. Callinectes sapidus and C. similis. Growth and molting phenomena in crabs exposed to $28 \mathrm{~d}$ of hypoxia at $30 \% \mathrm{~S}$ and $24^{\circ} \mathrm{C}$. Crabs exposed to 0 Torr $\mathrm{O}_{2}$ died within a few days and did not molt or grow. Sixteen crabs were used at each $\mathrm{PO}_{2}$ for each species. Sap: C. sapidus; $\operatorname{Sim}$ : $C$. similis

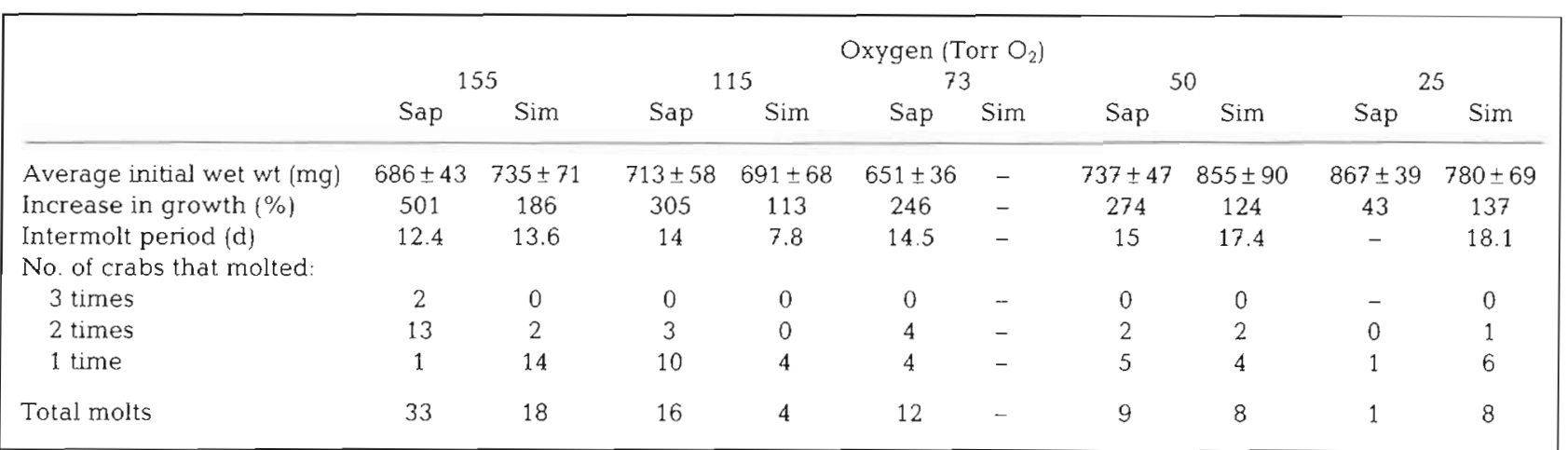



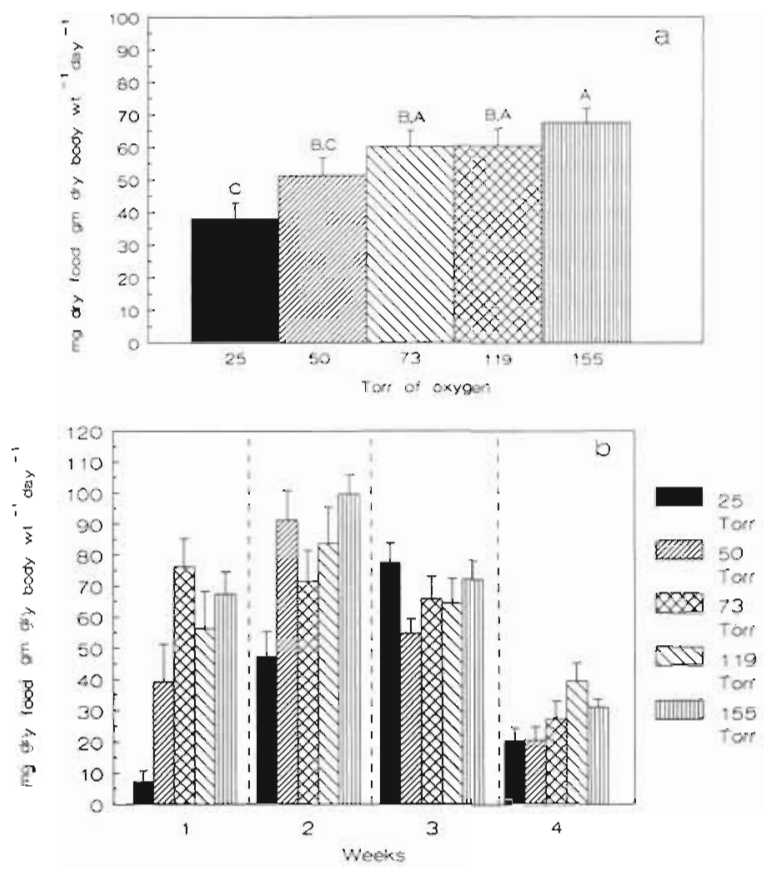

Fig. 5. Stramonita haemastoma. (a) Average feeding rate ( \pm SE) per unit dry body weight as a function of hypoxia. Means with the same letter are not significantly different from each other (Tukey's range test). (b) Mean weekly feeding rate $( \pm \mathrm{SE})$ as a function of hypoxia

cantly $(p<0.01)$ during the post-transfer period compared to their feeding rate when exposed to hypoxia (pre-transfer period, Fig. 6a). During the pre-transfer period molting rate was faster in the crabs exposed to normoxia compared to those exposed to various hypoxic levels. But, during the post-transfer period molting rate was much faster in the crabs previously exposed to hypoxia than in those exposed to normoxia (Fig. 6b).

\section{Response of Callinectes sapidus to starvation}

After a period of $10 \mathrm{~d}$ starvation, feeding rate of the blue crabs increased sharply above the pre-starvation feeding rate. The mean increase over the prestarvation feeding rate was $78 \pm 7 \mathrm{mg}$ wet food $\mathrm{g}^{-1}$ wet body wt $\mathrm{d}^{-1}$ which equals a $123 \%$ increase and was found to be highly significant (Student's $t$-test, $p<0.01$ ). This huge increase is attributable to the first $2 \mathrm{~d}$ of the $10 \mathrm{~d}$ post-starvation period (Fig. 6c). However, this elevated feeding rate of the blue crabs during the $10 \mathrm{~d}$ post-starvation period accounted for only $31 \%$ of the calculated deficit incurred during the starvation period.

\section{Oxygen consumption in Callinectes sapidus and C. similis}

Respiration was measured on Day 0 upon the direct transfer from normoxic water to various levels of hypoxic water to obtain the acute response. Respiration was also measured on crabs exposed to various levels of hypoxia for Days 1, 7, 14, 21 and 28. A significant $(p<0.001)$ difference in the weight specific oxygen consumption rate between the 2 species of crabs was observed with increasing duration of hypoxic exposure. The acute response of Callinectes sapidus on Day 0 was a lower rate of oxygen consumption at 25 and 50 Torr $\mathrm{O}_{2}$ compared to the normoxic consumption and a relatively higher rate at 115 Torr (Fig. 7 a). The increase continued at 50 and 115 Torr on Day 1 and the 25 Torr remained at the same level. Oxygen consumption remained depressed or the same as the normoxic crabs during the rest of the hypoxic exposure at all the hypoxic levels. Oxygen consumption in $C$. sapidus varied between days within a level and between levels within a day. A signif-

Table 2. Callinectes sapidus and Stramonita haemastoma. Scope for growth under normoxic, different levels of hypoxic, and anoxic conditions. Energy budgets given in $\mathrm{kJ} \mathrm{g}^{-1}$ dry body wt $\mathrm{d}^{-1} \%$ : percent of normoxic energy budget. Variables refer to the balanced energy equation (Winberg 1960); see text

\begin{tabular}{|c|c|c|c|c|c|c|c|c|}
\hline \multirow{2}{*}{$\begin{array}{l}\text { Oxygen concentration } \\
\text { (Torr) }\end{array}$} & \multirow[t]{2}{*}{$\mathrm{N}$} & \multirow{2}{*}{\multicolumn{2}{|c|}{$\begin{array}{l}\text { Energy consumed }(C) \\
\left(\mathrm{kJ} \mathrm{g}^{-1} \mathrm{~d}^{-1}\right) \quad(\%)\end{array}$}} & \multirow{2}{*}{$\begin{array}{c}\text { Energy } \\
\text { absorbed }(A b)\end{array}$} & \multicolumn{2}{|c|}{ Energy lost $(R)$} & \multicolumn{2}{|c|}{ Scope for growth $(P)$} \\
\hline & & & & & $\left(\mathrm{kJ} \mathrm{g}^{-1} \mathrm{~d}^{-1}\right)$ & $(\%)$ & $\left(\mathrm{kJ} \mathrm{g}^{-1} \mathrm{~d}^{-1}\right)$ & $(\%)$ \\
\hline \multicolumn{9}{|l|}{ Callinectes sapidus } \\
\hline 155 & 16 & 6.15 & 100 & 2.74 & 0.44 & 100 & 2.3 & 100 \\
\hline 119 & 2 & 6.5 & 106 & 2.89 & 0.35 & 80 & 2.54 & 110 \\
\hline 73 & 6 & 6.2 & 101 & 2.76 & 0.23 & 52 & 2.53 & 110 \\
\hline 50 & 3 & 4.53 & 74 & 2.02 & 0.17 & 39 & 1.9 & 83 \\
\hline \multicolumn{9}{|l|}{ Stramonita haemastoma } \\
\hline 155 & 12 & 1.19 & 100 & 0.97 & 0.21 & 100 & 0.76 & 100 \\
\hline 119 & 12 & 1.07 & 90 & 0.87 & 0.17 & 81 & 0.7 & 92 \\
\hline 73 & 12 & 1.04 & 88 & 0.85 & 0.11 & 52 & 0.74 & 97 \\
\hline 50 & 12 & 0.89 & 75 & 0.72 & 0.08 & 38 & 0.64 & 84 \\
\hline 25 & 12 & 0.67 & 56 & 0.54 & 0.05 & 24 & 0.49 & 64 \\
\hline
\end{tabular}



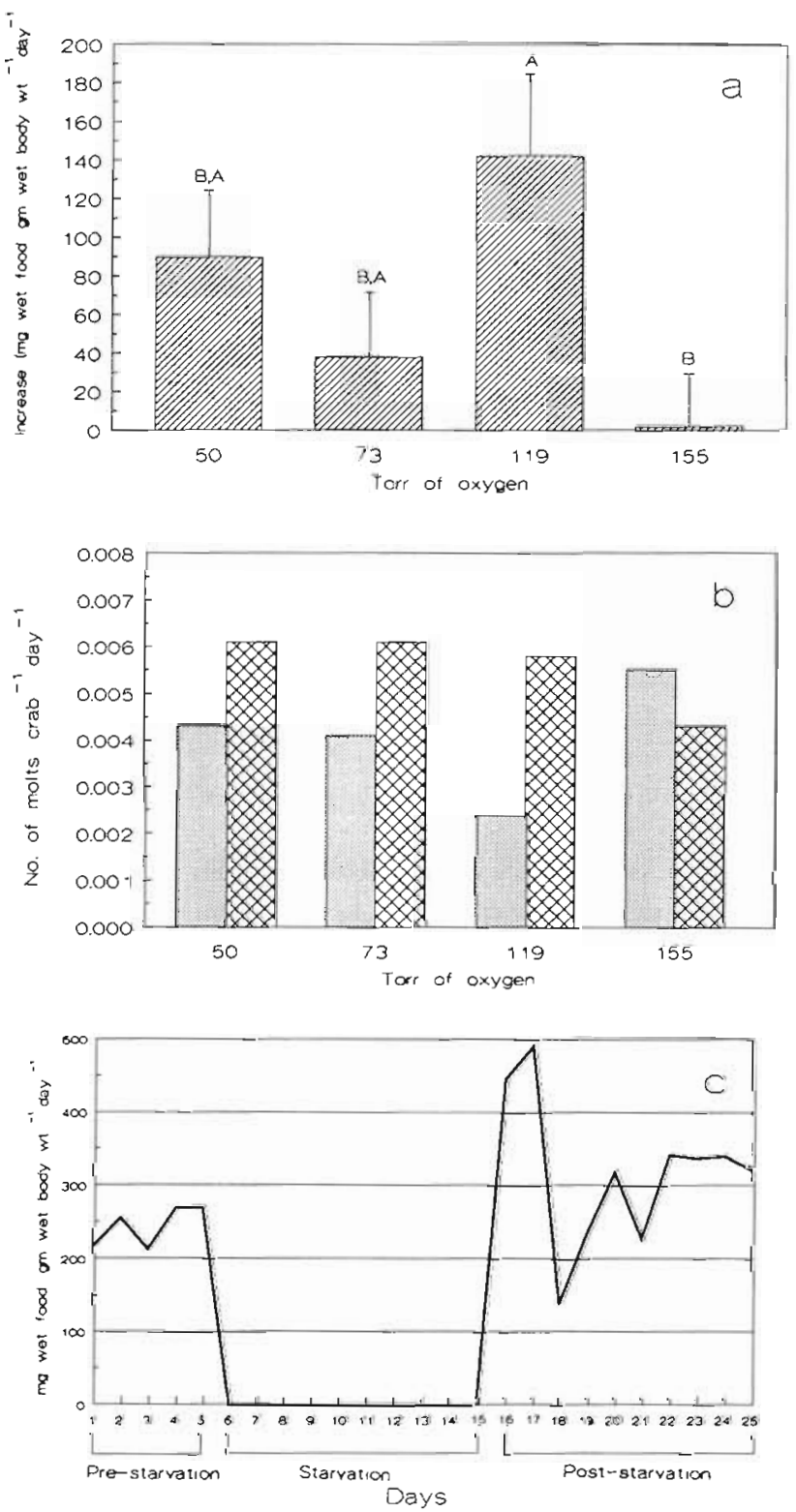

Fig. 6. Callinectes sapidus. (a) Increase in feeding rate during the post-transfer period in the transfer experiment when maintained at 3 levels of hypoxia for $10 \mathrm{~d}$ and then transferred to normoxia for $10 \mathrm{~d}$. Increase is shown by the mean difference $( \pm S E)$ in feeding rate before and after transfer to normoxia and plotted on the $y$-axis against various oxygen concentrations on the $x$-axis. Means with the same letter are not significantly different from each other (Tukey's range test). (b) Molting rate during the transfer experiment. Dotted bars represent the pre-transfer period and hatched bars represent the post-transfer period. (c) Mean daily feeding rate during the starvation experiment. A clear and sharp increase in the feeding rate can be noticed after Day 15 during the post-starvation period

icant $(\mathrm{p}<0.001)$ day by level interaction was found to exist. Blue crabs exposed to 25 and 50 Torr $\mathrm{O}_{2}$ exhibited a lower oxygen consumption rate than the crabs exposed to normoxia (Fig. 7).
The ratio of mean oxygen consumption within a hypoxic level over the period of $28 \mathrm{~d}$ to mean oxygen consumption in normoxic crabs over $28 \mathrm{~d}$ was used as an index to compare the integrated rate of oxygen consumption in hypoxic crabs to the normoxic ones. Values $>1$ indicate a higher level of oxygen consumption and values $<1$ indicate a possible oxygen debt (Fig. $7 \mathrm{c}$ ). Mean oxygen consumption in Callinectes sapidus exposed to various hypoxic levels was less than the crabs exposed to normoxic water. The acute response of $C$. similis was similar to C. sapidus on Day 0 , but the oxygen consumption rate in $C$. similis exposed to hypoxia remained elevated for the rest of the $28 \mathrm{~d}$ period. Significant $(p<0.01)$ differences in the oxygen consumption rate between levels as well as a significant day by level interaction were found in both $C$. sapidus and $C$. similis (Fig. 7 b). Mean oxygen consumption over $28 \mathrm{~d}$ at all hypoxic levels was $>1$ compared to the normoxic consumption in $C$. similis. Three-way factorial analysis showed significant differences $(p<0.001)$ in the oxygen consumption rate of the 2 species of crabs. All the lesser blue crabs exposed to hypoxia consumed more oxygen on an average compared to the blue crabs exposed to the same levels of hypoxia.

\section{DISCUSSION}

Callinectes sapidus was very sensitive to hypoxia with a $28 \mathrm{~d} \mathrm{LC}_{50}$ of 106 Torr $\mathrm{O}_{2}, \mathrm{C}$. similis was able to tolerate moderate hypoxia with a $28 \mathrm{~d} \mathrm{LC}_{50}$ of 43 Torr $\mathrm{O}_{2}$, and Stramonita haemastoma was very resistant to hypoxia with a $28 \mathrm{~d} \mathrm{LC}_{50}$ of 11.5 Torr $\mathrm{O}_{2}$. Stickle et al. (1989) found the $28 \mathrm{~d} \mathrm{LC}_{50}$ value for $C$. sapidus to be 111 Torr and for $S$. haemastoma to be 19 Torr $\mathrm{O}_{2}$. Kapper \& Stickle (1987) also reported S. haemastoma to be extremely tolerant of mild hypoxia. From the above data it seems clear that juvenile $C$. similis can tolerate hypoxia better than juvenile $C$. sapidus. These 2 species, especially the juvenile stages, compete for food and other resources most often (Engel 1977). DeFur et al. (1990) qualitatively demonstrated only $20 \%$ death of adult $C$. sapidus at moderate (50 Torr) hypoxia during 25 d exposure. Our findings are different for the juvenile blue crabs; $81 \%$ mortality was observed at 50 Torr over the $28 \mathrm{~d}$ period. All the crabs maintained at 25 and 0 Torr $\mathrm{O}_{2}$ died within a short period. This may be due to the higher oxygen demand per unit body mass in the juvenile blue crabs.

The feeding rate of neither Callinectes sapidus nor C. similis varied directly with the severity of hypoxia. Feeding rate of $C$. sapidus exposed to 50 Torr $\mathrm{O}_{2}$ was $74 \%$ of the normoxic feeding rate. Feeding rate of $C$. similis exposed to 50 and 25 Torr $\mathrm{O}_{2}$ was 84 and $82 \%$ respectively of the normoxic feeding rate. Meta- 
bolic rates of both species of crabs are not depressed in a comparable manner to that of the oyster drills and thus their metabolic demand for $\mathrm{O}_{2}$, when exposed to moderate hypoxia, remains close to the normoxic level and they die quickly when exposed to anoxia (Stickle et al. 1989). Blue crabs are not very good anaerobes (Carpenter \& Cargo 1957) and they are more dependent on their $\mathrm{O}_{2}$ transport system than most other groups of animals. Limited anaerobic metabolism exists in crustaceans involving pathways alternative to classical glycolysis with the production of L-lactate during exuviation and brief exposure to hypoxia (Fields 1985, Mangum et al. 1985b).

Weekly weight specific feeding rate of both species of crabs exhibited a steady decline over time with a steeper decline in Callinectes similis. Since this effect was consistent for hypoxic as well as normoxic crabs, the decline in feeding rate may not be due to hypoxic exposure, rather it may be due to increased body size or prolonged captivity. But the feeding rate per unit body weight was always lower in crabs exposed to hypoxia than those exposed to normoxia.

The importance of glucose in metabolic processes has been widely recognized. Because aerobic metabolic rate decreases in hypoxia-sensitive cells under oxygen limiting conditions, the demand for glucose for anaerobic glycolysis may rise dramatically to compensate for the energetic shortfall (Hochachka 1986). Glucose concentration in the blood depends on the rate of metabolism. The main source of metabolic energy in the crustaceans are glucose derivatives (Poolsanguan \& Uglow 1974). Oxygen consumed by crustaceans is used as the last acceptor of electrons in the respiratory process which usually begins with the degradation of carbohydrates (Rosas et al. 1992). Thus the feeding rate seems to be intimately related to the rate of oxygen consumption. We found in both species of crabs the metabolic rate remains at a very high level when exposed to various levels of hypoxia to cater to the greater need for glucose in the hypoxiasensitive cells. This creates a higher oxygen demand when the ambient oxygen tension is low.

Molting rate in both species of crabs was considerably higher for crabs exposed to normoxia (155 Torr $\mathrm{O}_{2}$ ) than those exposed to hypoxia though the overall
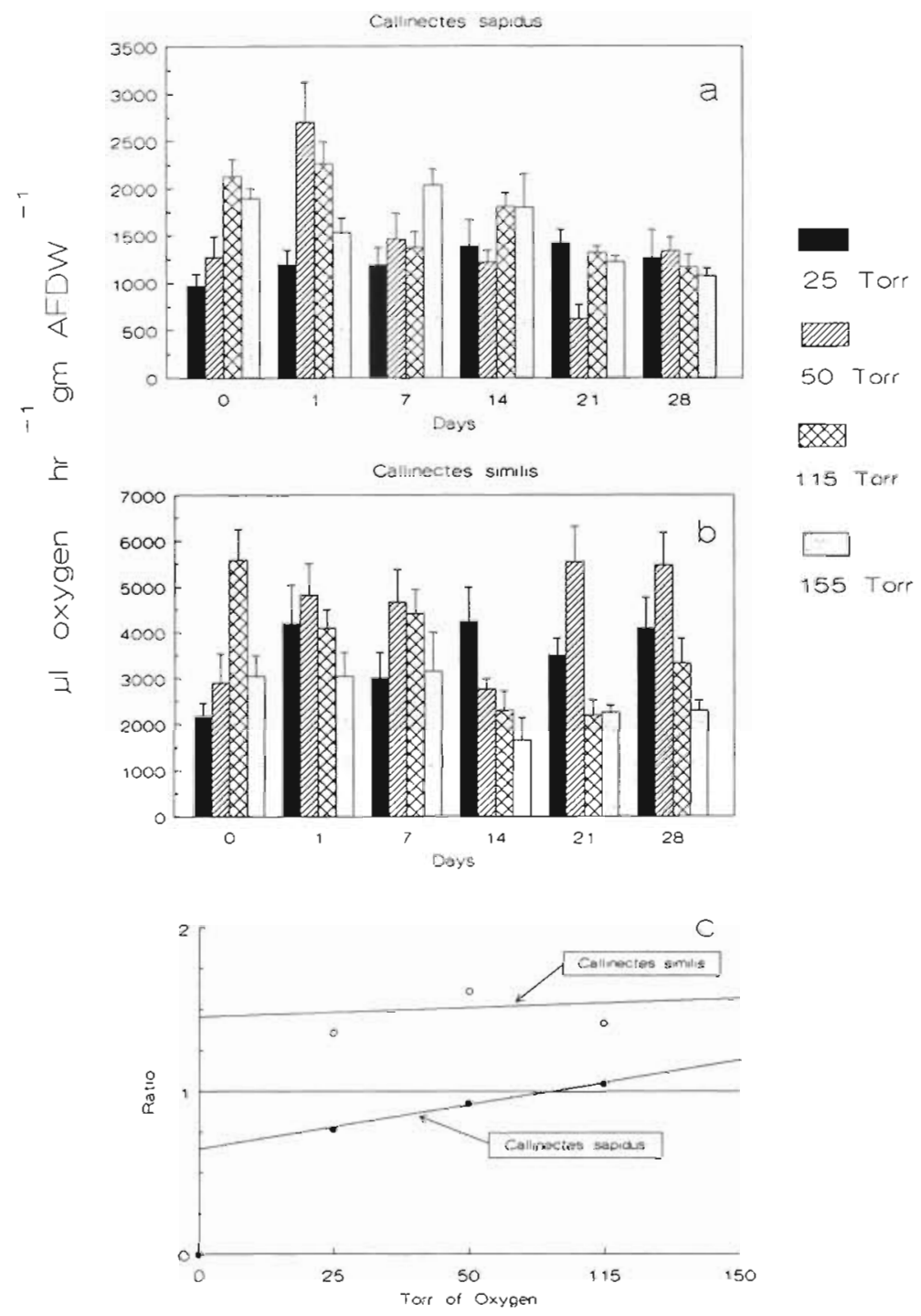

Fig. 7. Mean daily respiration ( $\pm \mathrm{SE}$ ) at various levels of hypoxia of (a) Callinectes sapidus and (b) $C$. similis. (c) Ratio of mean hypoxic oxygen consumption of the $2 \mathrm{crab}$ species within a level over $28 \mathrm{~d}$ to mean normoxic oxygen consumption over $28 \mathrm{~d}$ plotted against various oxygen concentrations. Normoxic oxygen consumption rate was fixed at 1 and is represented by the heavy line. A ratio of greater than 1 indicates a higher level of oxygen consumption compared to the normoxic consumption and a ratio of less than 1 indicates a possible oxygen debt

molting rate of Callinectes similis was much lower than C. sapidus. Frequent mortality while molting was observed in C. sapidus exposed to hypoxia. This was not observed in C. similis. Mangum et al. (1985a) showed that the hemocyanin in the hemolymph of a blue crab transports more than $95 \%$ of its $\mathrm{O}_{2}$ requirements and almost none is carried in the free form. They also reported that this system does not meet respiratory demand during molting when the metabolic demand is greater than usual. Due to increased uptake of water during molting, the hemocyanin in the blood is diluted 
to about one-fifth of the intermolt concentration which in turn reduces the $\mathrm{O}_{2}$ carrying capacity of the blood. This reduction in oxygen delivery is compounded by hypoxia and results in increased mortality in C. sapidus exposed to hypoxia while molting. In $C$. similis we failed to observe death during molting which probably suggests either an evolutionary adaptation to lengthen the intermolt period when exposed to hypoxia, possibly to avoid extra stress during an already existing environmental stressor, or a slower growth rate compared to C. sapidus. Glucose is necessary in the chitin synthesis upon molting (Rosas et al. 1992). Increasing the intermolt period and thus reducing the molting frequency is indeed an optimal adaptive strategy to reduce stress and thus the need for more glucose for chitin synthesis in $C$. similis. Because of this high demand for glucose, feeding rate did not decline directly with the severity of hypoxia in $C$. sapidus and the rate of oxygen consumption remained quite high.

Feeding rate in the oyster drills Stramonita haemastoma varied directly with the severity of hypoxia. Suppression of the metabolic rate of $S$. haemastoma at low oxygen tension may be responsible for the linear decline in their feeding rate with declining oxygen tension of the water (Stickle et al. 1989). The heat dissipation rate in $S$. haemastoma has been reported to be very low, only $9 \%$ of normoxia, when exposed to anoxia and oyster drills exhibit an oxygen debt upon return to normoxic water (Stickle et al. 1989). Metabolic rate depression in mollusks is possible because, instead of the classical and less efficient glycolysis system, they switch to relatively more efficient succinate and propionate pathways during exposure to hypoxia and anoxia (Gade 1983, Gnaiger 1983, 1987, de Zwaan \& Thillart 1985).

Weekly food consumption of the oyster drills within each treatment level showed a strong interaction with time. Oyster drills exposed to various treatment levels exhibited an increase in food consumption during the second week of the experiment loyster drills exposed to 50 Torr $\mathrm{O}_{2}$ also exhibited increase during the third week); the rate of food consumption then gradually declined over time in all levels. The initial shock of transfer from normoxia to hypoxia was probably responsible for the very low feeding rate during the first week after which they became acclimated and consumed more food. But with prolonged exposure their feeding rate could not be maintained and the rate of food consumption declined.

An estimate of the scope for growth under normoxia and different levels of hypoxia and anoxia in Callinectes sapidus and Stramonita haemastoma shows no significant difference in scope for growth at the 2 higher levels of hypoxia in $C$. sapidus. But in $S$. haemastoma a linear decline in the scope for growth occurs with the severity of hypoxia. S. haemastoma has a lower feeding and metabolic rate that results in a lower scope for growth which appears to be an adaptive advantage. When oyster drills are exposed to lower levels of dissolved oxygen in the water they restrict their metabolic demands for maintenance. As is true with exposure of marine invertebrate carnivores to other environmental stressor gradients (Stickle 1985), variation in energy consumption is much greater than variation in metabolic rate; $6: 1$ in juvenile C. sapidus and 3.3:1 in $S$. haemastoma. After a lower threshold limit of metabolic rate is reached in $S$. haemastoma at intermediate water temperature $\left(24^{\circ} \mathrm{C}\right)$, this metabolic rate reduction becomes futile as when oyster drills were exposed to anoxic water.

Crustaceans compensate for short-term hypoxia by increasing ventilation (Batterton \& Cameron 1978, Taylor 1982, Pease \& DeFur 1987), increased extraction efficiency (Hagerman \& Uglow 1985), and/or oxygen affinity of the hemocyanin (Hagerman \& Uglow 1985, DeFur et al. 1990). We observed an increase in oxygen consumption at all hypoxic levels in Callinectes similis at least by Day 1 compared to the normoxic crabs. Oxygen consumption remained at this elevated rate for the rest of the $28 \mathrm{~d}$ hypoxic exposure, which demonstrates a clear overcompensation in this species. In C. sapidus, oxygen consumption in the hypoxic crabs varied within a narrow limit around the normoxic consumption showing a partial compensatory acclimation over the 28 d hypoxic exposure. The increased oxygen consumption in $C$. similis may be due to both increased ventilation and an increased extraction efficiency. Sanchez et al. (1991) demonstrated higher extraction efficiency in $C$. similis per unit of metabolically active biomass among 6 different crustacean species studied.

In decapod crustaceans, hemocyanin in the blood is responsible for a very large fraction of the oxygen supplied to metabolizing tissue. The transport mechanism is perturbed during and immediately following a molt (Mangum et al. 1985b). During the pre-molt period a decrease in blood calcium, which acts as an allosteric effector that may increase oxygen affinity of hemocyanin, that accompanies hardening of the new shell lowers the hemocyanin oxygen affinity (Mangum et al. 1985b). Thus an increased supply of oxygen is necessary at this stage of the molt cycle. In our experiment under hypoxic exposure, oxygen consumption in Callinectes sapidus showed no increase with extreme of hypoxia. Average oxygen consumption was lower than normoxic consumption, but the feeding rate remained unchanged. Thus, the metabolic demand during molting was higher and the supply of oxygen was low. This probably was the main cause of death during molting in $C$. sapidus. In $C$. similis the opposite is true. 
They maintained a higher rate of oxygen consumption throughout the hypoxic exposure and the frequency of molting was less compared to $C$. sapidus. The extra amount of oxygen was probably used for metabolic maintenance, increasing the likelihood of survival.

In the direct transfer experiment no significant difference in the rate of food consumption existed with hypoxia over $10 \mathrm{~d}$ though the hypoxic crabs always exhibited lower food consumption rates compared with the crabs exposed to normoxia. But when the crabs were transferred back to normoxia (post-transfer period), the food consumption rate of the crabs previously exposed to hypoxia increased sharply. It is probable that the rate of adaptation from hypoxia to normoxia is much faster than from normoxia to hypoxia since the feeding adaptations in the blue crabs associated with hypoxic exposure seem to be very minor. The starvation experiment created a similar type of response as was noticed after the transfer of the crabs from hypoxic to normoxic water in the transfer experiment. The food consumption rate increased very sharply and stayed at that elevated level.

Tolerance to hypoxia is possibly also related to the developmental history of the blue crab. Complete acclimation to hypoxia has not been reported for either of the 2 species in the laboratory. But partial acclimation to frequently occurring patchy hypoxia in the Gulf of Mexico may be possible. Occurrence of widespread hypoxia is a regular phenomenon in the northern Gulf of Mexico during the summer months. Crustaceans can avoid hypoxia by swimming away from deeper to shallower water (Loesch 1960, May 1973, Pavela et al. 1983, Renaud 1986b, Pihl et al. 1991), but some exposure to hypoxia may be unavoidable when the hypoxic water mass is very wide spread. It is reasonable that some acclimation occurs in blue crabs and lesser blue crabs to these frequently occurring events which probably helps them to resist short-term hypoxia. Depending on the acclimation history of the crab population, hypoxia tolerance will vary and so will other responses related to it.

Acknowledgements. The authors gratefully acknowledge the invaluable help of Drs James T. Geghan, J. N. McCall and Marieanne Hollay in doing the statistical analyses. The editorial assistance of Drs J. Fleeger, D. W. Foltz, J. F. Siebenaller and K. M. Brown is gratefully acknowledged. The authors are grateful for the invaluable suggestions of the anonymous referees and the editorial assistance of Dr J. Lawrence.

\section{LITERATURE CITED}

Batterton, C. V., Cameron, J. N. (1978). Characteristics of resting ventilation and response to hypoxia, hypercapnia, and emersion in the blue crab Callinectes sapidus (Rathbun). J. exp. Zool. 203: 403-418
Bedinger, C. A., Childers, R. E., Cooper, J. W., Kimball, K. T., Kwok, A. (1981). Pollution fate and effect studies. In: Bedinger, C. A. (ed.) Ecological investigations of petroleum production platforms in the central Gulf of Mexico, Vol. 1, Part 1. Final report to the Bureau of Land Management, Contract No. A5551-CT9-17, New Orleans, p. 1-53

Boesch, D. F. (1983). Implication of oxygen depletion on the continental shelf of the northern Gulf of Mexico. Coastal Ocean Pollut. Assess. News. 2: 25-28

Cake, E. W. (1983). Habitat suitability index models: Gulf of Mexico American oyster. FWS/OBS - 82/10.57 U.S. Dept of Interior, Fish and Wildlife Service, Washington, DC

Cameron, J. N. (1978). NaCl balance in blue crabs, Callinectes sapidus, in fresh water. J. comp. Physiol. 123: 127-135

Carpenter, J. H., Cargo, D. G. (1957). Oxygen requirement and mortality of the blue crab in the Chesapeake Bay. Chesapeake Bay Inst. Tech. Rep. 13: 22

Churchill, E. P. Jr (1919). Life history of the blue crab. Fish Bull. Fish Wildl. Serv. U.S. 36: 95-128

Costlow, J. D. Jr, Bookhout, C. G. (1959). The larval development of Callinectes sapidus Rathbun reared in the laboratory. Biol. Bull. 116: 373-396

DeFur, P. L., Mangum, C. P., Reese, J. E. (1990). Respiratory responses of the blue crab Callinectes sapidus to long term hypoxia. Biol. Bull. 178: 46-54

de Zwaan, A., Thillart, G. V. D. (1985). Low and high power output modes of anaerobic metabolism: invertebrate and vertebrate strategies. In: Gilles, R. (ed.) Circulation, respiration and metabolism: current comparative approaches. Springer-Verlag, Berlin, p. 166-192

Engel, D. W. (1977). Comparison of the osmoregulatory capabilities of two portunid crabs, Callinectes sapidus and C. similis. Mar. Biol. 41: 275-279

Fields, J. H. A. (1985). A note on anaerobic metabolism in Callinectes sapidus during the intermolt cycle. J. crust. Biol. 5(2): 242-248

Gade, G. (1983). Energy metabolism of arthropods and mollusks during environmental and functional anaerobiosis. J. exp. Zool. 228: 415-429

Garlo, E. V., Milstein, C. B., Jahn, A. E. (1979). Impact of hypoxic conditions in the vicinity of Little Egg Inlet, New Jersey in summer 1976. Estuar. coast. mar. Sci. 8: 421-432

Georgia Cooperative Fishery and Wildlife Research Unit (1989). Species profiles: life histories and environmental requirements of coastal fishes and invertebrates (Mid Atlantic). Blue Crab Biological Report. Athens

Gnaiger, E. (1983). Heat dissipation and energetic efficiency in animal anoxibiosis: economy contra power. J. exp. Zool. 228: $471-490$

Gnaiger, E. (1987). Optimum efficiencies of energy transformations in anoxic metabolism. The strategies of power and economy. In: Calow, P. (ed.) Evolutionary physiological ecology. Cambridge University Press, Cambridge, p. 7-36

Guerin, J. L., Stickle, W. B. (1992). The effects of salinity on the tolerance and bioenergetics of juvenile blue crabs (Callinectes sapidus Rathbun) from different salinities. Mar. Biol. 114: 391-396

Gulf Coast Research Laboratory (1986). Species profiles: life histories and environmental requirements of coastal fishes and invertebrates, Gulf of Mexico. Blue Crab Biological Report. Ocean Springs, MS

Gunter, G. (1938). The common blue crab in fresh water (Callinectes sapidus). Science 87: 87-88

Hagerman, L., Uglow, R. F. (1985). Effects of hypoxia on the respiratory and circulatory regulation of Nephrops norvegicus. Mar. Biol. 87: 273-278

Hamilton, M. A., Russo, R. C., Thurston, R. V. (1977). Trimmed 
Spearman-Karber method for estimating median lethal concentrations in toxicity bioassay. Environ. Sci. Technol. 11: $714-719$

Hochachka, P. W. (1986). Defense strategies against hypoxia and hypothermia. Science 231: 234-241

Hsueh, P., McClintock, J. B., Hopkins, T S. (1991). Natural diets of the blue crabs Callinectes similis and $C$. sapidus in Mobile Bay, Alabama. Am. Zool. 31(5): $27 \mathrm{~A}$

Kapper, M. A., Stickle, W. B. (1987). Metabolic responses of the estuarine gastropod Thais haemastoma to hypoxia. Physiol. Zool. 60(1): 159-173

Loesch, H. (1960). Sporadic mass shoreward migrations of demersal fish and crustaceans in Mobile Bay, Alabama. Ecology 41(2): 292-298

Mangum, C. P., DeFur, P. L., Fields, J. H. A., Henry, R. P., Kkormanik, G. A., McMahon, B. R., Ricci, J., Towle, D. W., Wheatly, M. G. (1985a). Physiology of the blue crab Callinectes sapidus Rathbun during a molt. In: Perry, H. M., Malone, R. F. (eds.) Proc. Nat. Symp. on the Soft-shelled Blue Crab Fishery, February 12-13. Gulf Coast Research Laboratory, Biloxi, MS, p. 1-12

Mangum, C. P., McMahon, B. R., DeFur, P. L., Wheatly, M. G. (1985b). Gas exchange, acid-base balance, and the oxygen supply to the tissues during a molt of the blue crab Callinectes sapidus. J. crust. Biol. 5(2): 188-206

Mangum, C. P., van Winkle, W. (1973). Responses of aquatic invertebrates to declining oxygen conditions. Am. Zool. 13: $529-541$

May, E. B. (1973). Extensive oxygen depletion in Mobile Bay, Alabama. Limnol. Oceanogr. 18(3): 353-366

Odum, H. T. (1953). Factors controlling marine invasion into Florida freshwater. Bull. mar. Sci, Gulf Caribb. 3: 134-156

Officer, C. B., Biggs, R. B., Taft, J. L., Cronin, L. E., Tyler, M. A., Boynton, W. R. (1984). Chesapeake Bay anoxia: origin, development and significance. Science 223: 22-27

Parker, C. A., O'Reilly, J. E. (1991). Oxygen depletion in Long Island Sound: a historical perspective. Estuaries 14(3): $248-264$

Pavela, J. S., Ross, J. L., Chittenden, M. E. Jr (1983). Sharp reductions in abundance of fishes and benthic macroinvertebrates in the Gulf of Mexico off Texas associated with hypoxia. NE Gulf Sci. 6(2): 167-173

Pease, A. L., DeFur, P. L. (1987). Effect of long term hypoxia on respiratory and circulatory function of blue crabs, Callinectes sapidus. Am. Zool. 7(4): 109A

Pihl, L., Baden, S. P., Diaz, R. J. (1991). Effects of periodic hypoxia on distribution of demersal fish and crustaceans. Mar. Biol. 108: 349-360

Poolsanguan, B., Uglow, R. F. (1974). Quantitative changes in blood sugar levels of Crangon vulgaris. J. comp. Physiol. 93: $1-6$

Portnoy, J. W. (1991). Summer oxygen depletion in a diked New England estuary. Estuaries 14(2): 122-129

This article was presented by J. M. Lawrence, Tampa, Florida, USA
Rabalais, N. N., Turner, R. E., Wiseman, W. J. Jr, Boesch, D. F. (1986a). Hydrographic, biological, and nutrient characteristics of the water column in the Mississippi River Delta Bight, June, 1985 to December, 1985. Data Report No. 2, Louisiana Universities Marine Consortium, Chauvin

Rabalais, N. N., Turner, R. E., Wiseman, W. J. Jr, Boesch, D. F (1986b). Hydrographic, biological, and nutrient characteristics of the water column on the Louisiana Shelf, July and September, 1985. Data Report No. 3, Louisiana Universities Marine Consortium, Chauvin

Renaud, M. L. (1986a). Hypoxia in Louisiana coastal waters during 1983: implications for fisheries. Fish. Bull. U.S. 84: $19-26$

Renaud, M. L. (1986b). Detecting and avoiding oxygen deficient sea water by brown shrimp, Penaeus aztecus (Ives), and white shrimp, Penaeus setiferus (Linnaeus). J. exp. mar. Biol. Ecol. 98: 283-292

Rosas, C., Sanchez, A., Escobar, E., Soto, L., BolongaroCrevenna, A. (1992). Daily variations of oxygen consumption and glucose haemolymph level related to morphophysiological and ecological adaptations of crustacea. Comp. Biochem. Physiol. 101A(2): 323-328

Sanchez, A., Rosas, C., Escobar, E., Soto, L. (1991). Skeleton weight-free oxygen consumption related to adaptations to environment and habits of six crustacean species. Comp. Biochem. Physiol. 100A(1): 69-73

Sanford, P. L., Sellner, K. G., Breitburg, D. L. (1990). Covariability of dissolved oxygen with physical processes in the summertime Chesapeake Bay. J. mar. Res. 48: 567-590

SAS Institute, Inc. (1989). SAS/STAT user's guide, version 6 , 4 th edn. Cary, NC

Stickle, W. B. (1985). Effects of environmental factor gradients on scope for growth in several species of carnivorous marine invertebrates. In: Gray, J. S., Christiansen, M. E. (eds.) Marine biology of polar regions and effects of stress on marine organisms. John Wiley \& Sons Ltd, London, p. $601-616$

Stickle, W. B., Kapper, M. A., Liu, L. L., Gnaiger, E., Wang, S. (1989). Metabolic adaptations of several species of crustaceans and mollusks to hypoxia: tolerance and microcalorimetric studies. Biol. Bull, 177: 303-312

Taylor, E. W. (1982). Control and co-ordination of ventilation and circulation in crustaceans: response to hypoxia and exercise. J. exp. Biol 100: 289-319

Turner, R. E., Allen, R. L. (1982). Bottom water oxygen concentration in the Mississippi River Delta Bight. Contr. mar. Sci. 25: 161-172

Williams, A. B. (1984). Shrimps, lobsters and crabs of the Atlantic coast of the eastern US Maine to Florida. Smithsonian Institution Press, Washington, DC

Winberg, C. G. (1960). Rate of metabolism and food requirements of fishes. Transl. Ser. Fish. Res. Bd Can. 194: 202 